\title{
Pengaruh Corporate Social Responsibility, Dewan Komisaris Independen Dan Kepemilikan Institusional Terhadap Nilai Perusahaan Dengan Perencanaan Pajak Sebagai Variabel Moderating
}

\author{
Yamasitha \\ Universitas Putra Indonesia YPTK Padang,Indonesia \\ E-mail : yamasitha@upiyptk.ac.id
}

\begin{abstract}
Abstrak
Tujuan dari penelitian ini adalah untuk mengetahui corporate social responsibility, dewan komisaris independen dan kepemilikan institusional terhadap nilai perusahaan dengan perencanaan pajak sebagai variabel moderating. Metode pengumpulan sampel dengan menggunakan purposive sampling, dengan jumlah smapel sebanyak 30 perusahaan. Metode analisis yang digunakan adalah asumsi klasik dan linear berganda. Hasil penelitian yang didapatkan berdasarkan (uji t) diperoleh : (a) corporate social responsibility berpengaruh positif dan signifikan terhadap nilai perusahaan (b) dewan komisaris independen berpengaruh positif dan tidak signifikan terhadap nilai perusahaan (c) kepemilikan institusi berpengaruh positif dan tidak signifikan terhadap nilai perusahaan (d) prerencanaan pajak dapat memperlemah pengaruh hubungan corporate social responsibility terhadap nilai perusahaan (e) perencanaan pajak prerencanaan pajak dapat memperlemah pengaruh hubungan dewan komisaris independen terhadap nilai perusahaan (f) perencanaan pajak dapat memperkuat pengaruh hubungan kepemilikan institusi terhadap nilai perusahaan.
\end{abstract}

Kata kunci : Corporate Social Responsibility, Dewan Komisaris Independen, Kepemilikan Institusional, Perencanaan Pajak, Nilai Perusahaan.

\section{Pendahuluan}

Perusahaan merupakan suatu organisasi yang terdiri dari atas kelompok orang yang bekerja untuk mencapai suatu tujuan. Kepentingan yang paling mendasar yaitu mendapatkan keuntungan serta kesejahteraan bagi para pemegang saham perusahaan. Peningkatan nilai perusahaan yang tinggi merupakan tujuan jangka panjang yang seharusnya dicapai perusahaan, yang akan tercermin dari harga pasar sahamnya, karena penilaian investor terhadap perusahaan dapat diamati melalui pergerakan saham perusahaan.

Nilai perusahaan merupakan pencapaian sebuah perusahaan sebagai indikator dari kepercayaan pemegang saham terhadap perusahaan sejak berdirinya perusahaan sampai saat ini. Bagi perusahaan terbuka harga saham yang diperjualbelikan di pasar modal merupakan indikator nilai perusahaan. Nilai perusahaan sangat dibutuhkan, karena dengan peningkatan nilai perusahaan diharapkan mampu menarik pemegang saham untuk selalu berinvestasi pada perusahaan. Dengan peningkatan nilai perusahaan akan berpengaruh juga terhadap kesejahteraan karyawan, oleh sebab itu pihak yang ada di perusahaan dituntut untuk memanfaatkan kemampuan yang dimiliki semaksimal mungkin agar perusahaan lebih unggul dalam bersaing dibanding perusahaan lain.

Ada fenomena yang muncul pada perusahaan manufaktur yang menjadi top losers dalam perdagangan Bursa Efek Indonesia tahun 2017 dan dapat dilihat pada tabel dibawah ini : 
Tabel 1

Rata-Rata Nilai PBV Periode 2014-2018

\begin{tabular}{|c|c|c|c|c|c|c|c|}
\hline No & \multirow{2}{*}{ Emiten } & \multicolumn{5}{|c|}{ Tahun } & Persentase \\
\cline { 3 - 7 } & & 2014 & 2015 & 2016 & 2017 & 2018 & $(\%)$ \\
\hline 1 & BRAM & 1.01 & 0.83 & 1.13 & 1.13 & 0.86 & 0.99 \\
\hline 2 & PGAS & 3.95 & 1.60 & 1.54 & 0.98 & 1.11 & 1.83 \\
\hline 3 & WINS & 1.02 & 0.19 & 0.29 & 0.44 & 0.38 & 0.46 \\
\hline 4 & KBLV & 0.48 & 0.39 & 0.29 & 0.13 & 0.93 & 0.44 \\
\hline 5 & BBHI & 1.27 & 1.15 & 0.62 & 1.02 & 2.11 & 4.48 \\
\hline
\end{tabular}

Sumber: www.idx.co.id

Berdasarkan tabel diatas nilai perusahaan yang dihitung dengan PBV dari tahun 2014-2018 menunjukkan peningkatan dan penurunan yang sangat signifikan. Ada 5 perusahaan yang menunjukkan bahwa nilai perusahaan yang dikonfirmasikan melalui PBV bernilai positif karena PBV besar dari 1, ini menunjukkan bahwa nilai pasar saham lebih besar dari nilai bukunya. Sebaliknya jika nilai PBV kecil dari 1 berarti nilai pasar saham kecil dari nilai bukunya. Perbedaan PBV ini disebabkan karena perusahaan yang sedang tumbuh dan sangat agresif umumnya. Naik turunnya nilai harga saham tersebut dikarenakan adanya masalah dalam laporan keuangan terutama mengenai kepemilikan saham dan tata kelola perusahaan yang kurang baik dimana Corporate Social Responsibility (CSR) merupakan salah satu faktor yang menunjukkan baik atau tidaknya tata kelola perusahaan tersebut.

Nilai perusahaan yang tinggi dapat meningkatkan kemakmuran bagi para pemegang saham, sehingga para pemegang saham akan menginvestasikan modalnya kepada perusahaan tersebut (Prantama, Suhadak, \& Topowijono, 2015) . Pada umumnya, nilai perusahaan dipengaruhi oleh faktor keuangan dan faktor non keuangan. CSR merupakan salah satu faktor non keuangan yang sekarang ini perlu dipertimbangkan oleh perusahaan dalam upaya meningkatkan nilai perusahaan. CSR merupakan sebuah wacana yang menjadikan perusahaan tidak hanya berkewajiban atau beroperasi untuk pemegang saham (shareholders) saja namun juga mempunyai tanggung jawab sosial terhadap stakeholders.

Ketika perusahaan semakin berkembang, saat itu pula tingkat kesenjangan sosial dan kerusakan lingkungan semakin tinggi yang disebabkan adanya eksploitasi perusahaan secara tidak terkendali terhadap berbagai sumber daya untuk meningkatkan laba yang dapat mengganggu keseimbangan kehidupan. CSR terhadap nilai perusahaan sangatlah penting, karena dengan adanya CSR dipercaya dapat meningkatkan nilai perusahaan, dimana para investor cenderung menanamkan modalnya kepada perusahaan yang memiliki kepedulian sosial, dengan menggunakan informasi tanggung jawab sosial sebagai salah satu keunggulan perusahaannya yang berdampak langsung pada lingkungan. Oleh karena itu dengan adanya CSR, diharapkan bisa menjadi penawar bagi lingkungan dan masyarakat sekitar perusahaan. Dalam situasi seperti ini CSR dan GCG merupakan suatu keharusan untuk meminimalisir berbagai dampak negatif dari perusahaan tersebut dan dalam rangka membangun perusahaan yang tangguh dan sustainable (berkelanjutan).

Lemahnya penerapan GCG dikarenakan kurangnya kesadaran akan suatu nilai dan praktek dasar dalam menjalankan bisnis, seharusnya dengan adanya penerapan GCG mampu meningkatkan nilai perusahaan. Nilai perusahaan merupakan nilai yang harus dijaga dan dipertahankan oleh suatu perusahaan sebagai gambaran dari kepercayaan masyarakat terhadap perusahaan tersebut. GCG sebagai bentuk kepatuhan menjadi sesuatu yang memang penting dan dibutuhkan oleh korporasi agar mencapai pertumbuhan yang berkualitas dan berkesinambungan. Untuk itu, dibutuhkan suatu Kepemilikan Institusional yang terorganisir dan konsisiten untuk mengembangkan budaya baru berbasis GCG yang memungkinkan terciptanya proses pengambilan keputusan yang bertanggung jawab.

Menurut (Herry, 2015) Kepemilikan Institusional merupakan kepemilikan saham perusahaan oleh institusi seperti perusahaan asuransi, bank, perusahaan investasi, perusahaan investasi, reksa dana, dan institusi lainnya. Kepemilikan institusional yang tinggi 
menimbulkan pengawasan yang lebih besar oleh pihak investor intitusional sehingga dapat menghalangi perilaku opportunistic manajer. Kepemilikan institusional bertindak sebagai pengawas dalam kinerja perusahaan. Semakin baik tingkat pengawasan yang dilakukan maka akan mengakibatkan sistem bekerja dengan baik, meminimalkan tingkat pelanggaran dan kinerja manajemen juga akan meningkat yang secara langsung akan berdampak pada tingkat pendapatan perusahaan. Ketentuannya adalah jumlah komisaris independen sekurangkurangnya harus $30 \%$ dari seluruh anggota komisaris. Komisaris independen bisa merangkap sebagai ketua komite audit (Samsul, 2006). Semakin kecil jumlah komisaris independen akan berdampak terhadap kinerja perusahaan yang semakin meningkat. Karena hal ini tidak menimbulkan tumpang tindih informasi dan kebijakan yang nantinya akan disampaikan kepada direksi di perusahaan.

Menurut (Sulistyowati \& Ulfah, 2015) tujuan utama pendirian perusahaan adalah memaksimalkan laba. Selain itu, perusahaan sebagai wajib pajak badan mempunyai kewajiban untuk membayar pajak dengan benar. Jika bagi pemerintah pajak merupakan sumber pendapatan negara, sebaliknya bagi perusahaan pajak dianggap sebagai beban yang akan mengurangi keuntungan. Maka tak heran perencanaan pajak (tax planning) menjadi bagian yang tidak terpisahkan dari wajib pajak terutama perusahaan. Karena tujuan utama perencanaan pajak ialah mencari berbagai celah yang dapat ditempuh dalam koridor peraturan perpajakan (loopholes) agar perusahaan dapat membayar pajak dalam jumlah minimal, yang dapat dilakukan wajib pajak untuk menekan jumlah beban pajaknya, yakni dengan cara melakukan penghindaran pajak (tax avoidance), penyelundupan pajak (tax evasion), dan penghematan pajak (tax saving) (Pohan, 2016)

Kegiatan perencanaan pajak merupakan salah satu cara yang dilakukan untuk memanipulasi pelaporan keuangan perusahaan. Karena perencanaan pajak dilakukan dengan merekayasa dan mengelola transaksi keuangan yang ada dalam perusahaan untuk mendapatkan laba yang tinggi oleh sebab itu diperlukan tata kelola yang baik. Sehingga tidak merugikan investor yang akan menurunkan kepercayaan mereka juga menurunkan nilai perusahaan (Yuono \& Widaywati, 2016).

\section{Landasan Teori}

\subsection{Teori Agency}

Menurut (Jensen \& Meckling, 1976) menyatakan bahwa teori keagenan mendeskripsikan pemegang saham sebagai prinsipal dan manajemen sebagai agen. Manajemen merupakan pihak yang dikontrak oleh pemegang saham untuk bekerja demi kepentingan pemegang saham. Untuk itu manajemen diberikan sebagian kekuasaan untuk membuat keputusan bagi kepentingan terbaik pemegang saham. Oleh karena itu, manajemen wajib mempertanggungjawabkan semua upayanya kepada pemegang saham.

\subsection{Nilai Perusahaan}

Nilai perusahaan merupakan persepsi investor terhadap suatu perusahaan yang berkaitan dengan harga saham. Semakin tinggi nilai perusahaan menggambarkan semakin sejahtera pula perusahaan tersebut. Nilai perusahaan yang tinggi memiliki dampak kemakmuran bagi para pemegang saham (stakeholder), sehingga para pemegang saham menginvestasikan modalnya ke perusahaan tersebut (Haruman, 2018).

\subsection{Corporate Social Responsibility}

Pertanggungjawaban sosial perusahaan atau Corporate Social Responsibility (CSR) adalah mekanisme bagi suatu organisasi untuk secara sukarela mengintegrasikan perhatian terhadap lingkungan dan sosial ke dalam operasinya dan interaksinya dengan stakeholders, yang melebihi tanggungjawab organisasi di bidang hukum (Anggraini, 2016).

\subsection{Dewan Komisaris Independen}

Berdasarkan UU No. 40 tahun 2007 tentang Perseroan Terbatas mendefinisikan dewan komisaris adalah organ perseroan yang bertugas melakukan pengawasan secara umum dan atau 
khusus sesuai dengan anggaran dasar serta memberi nasehat kepada direksi. Dewan komisaris independen merupakan komisaris yang tidak mempunyai ikatan bisnis atau hubungan keluarga dengan pemegang saham maupun direksi (Widyaningsih, 2018).

\subsection{Kepemilikan Institusional}

Menurut (Hery, 2017) kepemilikan institusional adalah proporsi pemegang saham yang dimiliki oleh pemilik institusi misalnya asuransi, bank, perusahaan investasi serta kepemilikan institusi lainnya. Perusahaan dengan kepemilikan institusional yang besar mengidentifikasikan kemampuannya dalam memonitor manajemen.

\subsection{Perencanaan Pajak}

Menurut Pradnyana \& Noviari (2017) mengemukakan pengertian perencanaan pajak (tax planning) ialah "Tindakan penstrukturan yang terkait dengan konsekuensi potensi pajaknya, yang tekanannya kepada pengendalian setiap transaksi yang ada konsekuensi pajaknya. Tujuannya adalah bagaimana pengendalian tersebut dapat mengefisiensi jumlah pajak yang akan ditransfer ke pemerintah, melalui apa yang disebut sebagai penghindaran pajak (tax avoiadance) dan bukan penyelundupan pajak (tax evasion) yang merupakan tindak pidana fiskal yang tidak akan ditoleransi”.

\subsection{Kerangka Pikir}

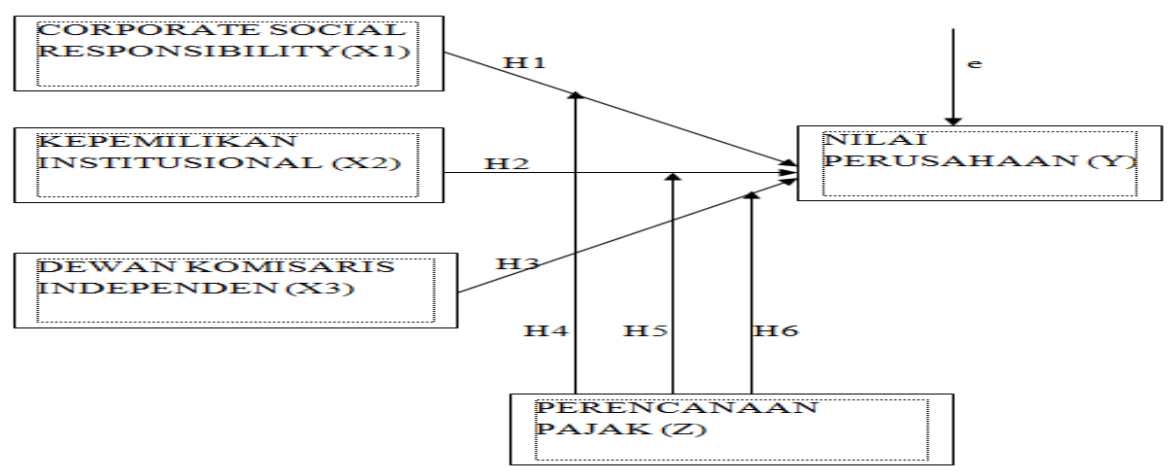

Gambar 1. Kerangka Pikir

\section{Metodologi Penelitian}

\subsection{Jenis Data Dan Teknik Pengumpulan Data}

Metode yang digunakan dalam penelitian ini adalah metode deskriptif verifikatif dengan pendekatan kuantitatif. Data kuantitatif, yaitu data dalam bentuk angka-angka dan dapat dinyatakan dalam satuan hitung (Sugiyono, 2017). Dalam penelitian ini menggunakan metode deskriptif verifikatif tersebut digunakan untuk menguji lebih dalam corporate social responsibility, dewan komisaris independen dan kepemilikan institusional terhadap nilai perusahaan dengan perencanaan pajak sebagai variabel moderating pada perusahaan manufaktur yang terdaftar di Bursa Efek Indonesia. Jenis data yang digunakan pada penelitian ini adalah data sekunder, yaitu data yang diperoleh secara tidak langsung dengan mempelajari litelatur atau dokumen yang berhubungan dengan laporan keuangan yang diteliti berupa laporan keuangan tahunan (annual report) perusahaan pada tahun 2014-2018 yang terdaftar pada BEI.

\subsection{Populasi dan sampel}

Populasi menurut (Sugiyono, 2017) Populasi adalah wilayah generalisasi yang terdiri atas objek atau subjek yang mempunyai kualitas dan karakteristik tertentu yang ditetapkan oleh peneliti untuk dipelajari dan kemudian ditarik kesimpulannya. Populasi sasaran yaitu populasi yang digunakan untuk menjadi sasaran penelitian. 
Populasi yang digunakan dalam penelitian ini adalah perusahaan manufaktur yang berjumlah 167 perusahaan yang dibatasi dengan sektor industri barang dan konsumsi yang terdaftar di Bursa Efek Indonesia pada tahun 2014-2018. Sampel dalam penelitian ini adalah Perusahaan Manufaktur. Pemilihan sampel penelitian berdasarkan pada purposive sampling dengan tujuan mendapatkan sampel yang representatif sesuai kriteria yang telah ditentukan. Penentuan jumlah sampel dalam penelitian ini dengan menggunakan teknik puposive sampling dalam rangka mendapatkan sampel sebanyak 30 perusahaan.

\subsection{Pengukuran Variabel}

Nilai perusahaan dalam penelitian ini dikonfirmasikan melalui Price Book Value (PBV) (Ross, Stephen, \& Westerfield, 2015) adalah sebagai berikut:

$$
\mathrm{PBV}=\frac{\text { Harga Saham }}{\text { Nilai Buku Saham }}
$$

CSR adalah bagaimana perusahaan mengelolah bisnis untuk menghasilkan dan berdampak posistif secara keseluruhan kepada masyarakat (Ardiyanto \& Haryanto, 2017). Adapun rumus untuk menghitung CSR adalah :

$$
C S R=\frac{\text { Jumlah Item Pengungkapan CSR yang dipenuhi }}{\text { Jumlah semua item Pengungkapan CSR }} \times 100 \%
$$

Komisaris Independen yang berasal dari luar perusahaan dari seluruh anggota dewan komisaris perusahaan. Indikator yang digunakan mengacu pada penelitian (Endraswati, 2017), Variabel ini diukur dengan rumus:

$$
\mathrm{DKI}=\frac{\text { Proporsi Komisaris Independen }}{\text { Jumlah Komisaris Pada Perusahaan }} \times 100 \%
$$

Kepemilikan Institusional yaitu proposri kepemilikan saham institusional pada akhir tahun yang diukur dalam persentase saham yang dimiliki oleh investor institusional dalam suatu perusahaan. Indikator yang digunakan mengacu pada penelitian (Rimardhani, Hidayat, \& Dwiatmanto, 2016).Rumus perhitungan KI ini dapat dituliskan sebagai berikut:

$$
\mathrm{KI}=\frac{\text { Jumlah Saham Yang Dimiliki Institusional }}{\text { Jumlah Saham Yang Beredar }} \times 100 \%
$$

Perencanaan pajak ialah langkah pertama ketika melaksanakan manajemen pajak dan proses mengorganisasi dari usaha dan kelompok wajib pajak agar bisa meminimumkan kewajiban dari hutang pajak serta beban pajak perusahaan, selama masih diperbolehkan dalam peraturan perundang-undangan. Variabel ini diukur menggunakan Effective Tax Rate atau ETR seperti dalam penelitian (Khotimah, 2014). Adapun rumus untuk menghitung ETR adalah :

$$
\mathrm{ETR}=\frac{\text { Beban Pajak }}{\text { Laba Sebelum Pajak }}
$$




\section{Hasil dan Pembahasan}

\subsection{Model regresi data panel}

Berdasarkan uji chow, uji hausman dan uji langrangge multiplier dapat disimpulkan bahwa model regresi data panel pada penelitian ini menggunakan random effect model. Kemudian sebelum pemilihan model, data dinyatakan telah lolos dari uji asumsi klasik, sehingga hasil estimasi konsisten dan biasa. Hasil estimasi model regresi data panel sebagai berikut:

Tabel 2

\section{Hasil Estimasi Random Effect Model}

\begin{tabular}{ccccc}
\hline Variable & Coefficient & Std. Error & t-Statistic & Prob. \\
\hline C & -0.846477 & 0.554314 & -1.527072 & 0.1289 \\
CSR & 0.083479 & 0.017636 & 4.733305 & 0.0000 \\
DKI & 0.013706 & 0.008462 & 1.619671 & 0.1075 \\
KI & 0.001929 & 0.005347 & 0.360733 & 0.7188 \\
\hline
\end{tabular}

Sumber: output eviews 9 dan data sekunder (diolah,2019)

Berdasarkan model estimasi yang terpilih, diperoleh persamaan model regresi data panel sebagai berikut :

PBVit = -0,846477 + 0,083479 CSR ${ }_{\text {it }}+0,013706$ DKI $_{\text {it }}+0,001929 \mathrm{KI}_{\text {it }}$

1. Nilai konstanta $\alpha$ sebesar $-0,846477$ artinya jika variabel CSR, DKI dan KI pada observasi ke i dan periode ke $t$ di abaikan atau bernilai nol maka PBV sebesar --0,846477 persen.

2. Nilai koefisien $b_{1}$ sebesar 0,083479 artinya jika CSR pada observasi ke i dan periode ke $t$ meningkat sebesar satu (1) satuan, dengan asumsi variabel DKI dan KI diabaikan atau maka PCSR naik sebesar 0,083479 .

3. Nilai koefisien $b_{2}$ sebesar 0,013706 artinya jika nilai DKI pada observasi ke $i$ dan periode ke t meningkat sebesar satu (1) satuan, dengan asumsi variabel CSR dan KI diabaikan atau nol maka DKI naik sebesar 0,013706.

4. Nilai koefisien $b_{3}$ sebesar 0,001929 artinya jika nilai KI pada observasi ke i dan periode ke t meningkat sebesar satu (1) satuan, dengan asumsi variabel CSR dan DKI diabaikan atau nol maka KI naik sebesar 0,001929.

Tabel 3

Hasil Estimasi Random Effect Model dengan Moderating

\begin{tabular}{ccccc}
\hline Variable & Coefficient & Std. Error & t-Statistic & Prob. \\
\hline C & -0.839018 & 0.554785 & -1.512331 & 0.1327 \\
CSR & 0.084060 & 0.020827 & 4.036140 & 0.0001 \\
DKI & 0.008542 & 0.009825 & 0.869396 & 0.3861 \\
KI & 0.007044 & 0.005663 & 1.243718 & 0.2157 \\
CSR $*$ ETR & -0.006536 & 0.030146 & -0.216823 & 0.8287 \\
DKI*ETR & 0.012963 & 0.012224 & 1.060446 & 0.2908 \\
KI*ETR & -0.013204 & 0.006540 & -2.018906 & 0.0454 \\
\hline
\end{tabular}

Sumber: output eviews 9 dan data sekunder (diolah,2019)

Berdasarkan model estimasi yang terpilih, diperoleh persamaan model regresi data panel sebagai berikut :

PBVit = -0,839018 + 0,084060 CSR ${ }_{\text {it }}+0,008542$ DKI $_{\text {it }}+0,007044 \mathrm{KI}_{\text {it }}-0,006536$

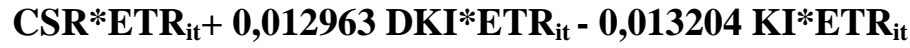


1. Nilai konstanta $\alpha$ sebesar $-0,839018$ artinya jika variabel CSR, DKI, KI, CSR*ETR, DKI*ETR dan KI*ETR pada observasi ke i dan periode ke t di abaikan atau bernilai nol maka PBV sebesar $-0,839018$ persen.

2. Nilai koefisien $b_{1}$ sebesar 0,0,084060 artinya jika CSR pada observasi ke i dan periode ke t meningkat sebesar satu (1) satuan, dengan asumsi variabel DKI, KI, CSR*ETR, DKI*ETR dan KI*ETR diabaikan atau nol maka CSR naik sebesar 0,084060.

3. Nilai koefisien $b_{2}$ sebesar 0,008542 artinya jika nilai DKI pada observasi ke i dan periode ke t meningkat sebesar satu (1) satuan, dengan asumsi variabel CSR, KI, CSR*ETR, DKI*ETR dan KI*ETR diabaikan atau nol maka DKI naik sebesar 0,008542 .

4. Nilai koefisien $b_{3}$ sebesar 0,006536 artinya jika nilai KI pada observasi ke i dan periode ke t meningkat sebesar satu (1) satuan, maka PBVnaik sebesar 0,006536 dengan asumsi variabel CSR, DKI dan CSR*ETR, DKI*ETR dan KI*ETR diabaikan atau nol maka KI naik sebesar 0,006536 .

5. Nilai koefisien $b_{3}$ sebesar $-0,006536$ artinya jika nilai CSR*ETR pada observasi ke i dan periode ke t meningkat sebesar satu (1) satuan, dengan asumsi variabel CSR, DKI, KI, DKI*ETR dan KI*ETR diabaikan atau nol maka CSR*ETR naik sebesar 0,006536.

6. Nilai koefisien $b_{3}$ sebesar 0,012963 artinya jika nilai DKI*ETR pada observasi ke i dan periode ke t meningkat sebesar satu (1) satuan, dengan asumsi variabel CSR, DKI, KI, CSR*ETR dan KI*ETR diabaikan atau nol maka DKI*ETR naik sebesar 0,012963.

7. Nilai koefisien $b_{3}$ sebesar -0,003204 artinya jika nilai KI*ETR pada observasi ke i dan periode ke t meningkat sebesar satu (1) satuan, dengan asumsi variabel CSR, DKI, KI, CSR*ETR dan DKI*ETR diabaikan atau nol maka KI*ETR turun k sebesar -0,003204.

\subsection{Uji Hipotesis}

\subsubsection{Koefisien Determinasi $\left(R^{2}\right)$}

Koefisien determinasi $\left(\mathrm{R}^{2}\right)$ menunjukkan proporsi yang diterangkan oleh independent variable dalam model terhadap dependent variable dan moderating variable .

\section{Tabel 4}

Hasil Uji Koefisien Determinasi $\left(\mathbf{R}^{2}\right)$ Tanpa Variabel Moderating

R-squared 0.156102

Adjusted R-squared 0.138521

Sumber: output eviews 9 dan data sekunder (diolah,2019)

Berdasarkan tabel 4.12 menunjukan bahwa nilai koefisien determinasi yang dihasilkan dalam pengujian $R$-squared bernilai 0,16 . Hasil yang diperoleh menunjukan bahwa variabel corporate social responsibility, dewan komisaris independen dan kepemilikan institusi mampu memberikan kontribusi dalam mempengaruhi nilai perusahaan sebesar $15 \%$ sedangkan sisanya 85\% lagi dipengaruhi oleh variabel lainnya yang tidak dimasukkan dalam model penelitian.

\section{Tabel 5}

Hasil Uji Koefisien Determinasi $\left(\mathbf{R}^{2}\right)$ dengan Moderating

\begin{tabular}{ll}
\hline R-squared & 0.205201 \\
Adjusted R-squared & 0.171379 \\
\hline
\end{tabular}

Sumber: output eviews 9 dan data sekunder (diolah,2019)

Berdasarkan tabel 4.13 menunjukan bahwa nilai koefisien determinasi yang dihasilkan dalam pengujian $R$-squared bernilai 0,205201. Hasil yang diperoleh menunjukan bahwa variabel corporate social responsibility, dewan komisaris independen dan kepemilikan institusi mampu memberikan kontribusi dalam mempengaruhi nilai perusahaan dengan prerencanaan pajak sebagai variabel pemoderasi sebesar $21 \%$ sedangkan sisanya $79 \%$ lagi dipengaruhi oleh variabel lainnya yang tidak dimasukkan dalam model penelitian. 


\subsubsection{Hasil Uji t (parsial)}

Uji t digunakan untuk menguji pengaruh independent variable secara parsial terhadap variable dependent dan moderating variable. Pengujian ini dilakukan dengan ketentuan :

1. Apabila probability thitung $<0,05$, maka Ho ditolak dan Ha diterima.

2. Apabila probability thitung $>0,05$, maka Ho diterima dan Ha ditolak.

Berdasarkan tabel 4.8 dan 4.9 menunjukan pengaruh variabel corporate social resonsibility, dewan komisaris independen dan kepemilikan institusional dengan perencanaan pajak sebagai variabel moderating dapat diuji sebagai berikut yaitu :

1. Corporate Social Responsibility terhadap Nilai Perusahaan

Hasil analisis menunjukkan corporate social responsibility memiliki nilai koefisien regresi sebesar 0,083479 dan $t_{\text {statistic }}$ sebesar 4,733305 dengan nilai probability sebesar 0,0000 kecil dari 0,05 atau $(0,0000<0,05)$. Maka dapat disimpulkan bahwa variabel corporate social responsibility secara parsial berpengaruh positif dan signifikan terhadap nilai perusahaan pada perusahaan manufaktur yang dibatasi dengan sektor barang dan konsumsi yang terdaftar di Bursa Efek Indonesiatahun 2014-2018. Sehingga Ho ditolak dan Ha diterima.

2. Dewan Komisaris Independen terhadap Nilai Perusahaan

Hasil analisis menunjukkan bahwa dewan komisaris independen memiliki nilai koefisien regresi sebesar 0,013706 dan $t_{\text {statistic }}$ sebesar 1,619671 dengan nilai probability sebesar 0,1075 lebih besar dari 0,05 atau $(0,1075>0,05)$. Maka dapat disimpulkan bahwa variabel Dewan Komisaris Independen secara parsial berpengaruh positif dan tidak signifikan terhadap nilai perusahaan pada perusahaan manufaktur yang dibatasi dengan sektor barang dan konsumsi yang terdaftar di Bursa Efek Indonesia tahun 2014-2018. Sehingga Ho diterima dan Ha ditolak.

3. Kepemilikan Institusi terhadap Nilai Perusahaan

Hasil analisis menunjukkan bahwa kepemilikan institusi memiliki nilai koefisien regresi sebesar 0,001929 dan $t_{\text {statistic }}$ sebesar 0,360733 dengan nilai probability sebesar 0,07188 lebih besar dari 0,05 atau $(0,7188>0,05)$. Maka dapat disimpulkan bahwa variabel kepemilikan institusi secara parsial berpengaruh positif dan tidak signifikan terhadap nilai perusahaan pada perusahaan manufaktur yang dibatasi dengan sektor barang dan konsumsi yang terdaftar di Bursa Efek Indonesia tahun 2014-2018. Sehingga Ho diterima dan Ha ditolak.

4. Corporate Social Responsibility terhadap Nilai Perusahaan dengan Perencanaan Pajak sebagai variabel moderating

Hasil analisis menunjukkan corporate social responsibility memiliki nilai koefisien regresi sebesar $-0,006536$ dan $t_{\text {statistic }}$ sebesar $-0,216823$ dengan nilai probability sebesar 0,8287 lebih besar dari 0,05 atau $(0,8287>0,05)$. Sehingga perencanaan pajak tidak mampu memoderasi pengaruh corporate social responsibility terhadap nilai perusahaan. Maka dapat disimpulkan bahwa variabel corporate social responsibility secara parsial berpengaruh positif dan tidak signifikan terhadap nilai perusahaan dengan perencanaan pajak sebagai variabel moderating pada perusahaan manufaktur yang dibatasi dengan sektor barang dan konsumsi yang terdaftar di Bursa Efek Indonesiatahun 2014-2018. Sehingga Ho diterima dan Ha ditolak.

5. Dewan komisaris independen terhadap Nilai Perusahaan dengan Perencanaan Pajak sebagai moderasi

Hasil analisis menunjukkan bahwa dewan komisaris independen memiliki nilai koefisien regresi sebesar 0,012963 dan $t_{\text {statistic }}$ sebesar 1,060446 dengan nilai probability sebesar 0,2908 lebih besar dari 0,05 atau $(0,2908>0,05)$. Sehingga perencanaan pajak tidak mampu memoderasi pengaruh dewan komisaris independen terhadap nilai perusahaan. Maka dapat disimpulkan bahwa variabel dewan komisaris independen secara parsial berpengaruh positif dan tidak signifikan terhadap nilai perusahaan dengan perencanaan pajak variabel moderating pada perusahaan manufaktur yang dibatasi dengan sektor barang dan konsumsi yang terdaftar di Bursa Efek Indonesia tahun 2014-2018. Sehingga 


\section{Ho diterima dan Ha ditolak.}

6. Kepemilikan Institusional terhadap Nilai Perusahaan dengan Perencanaan Pajak sebagai variabel moderasi

Hasil analisis menunjukkan bahwa kepemilikan institusi memiliki nilai koefisien regresi sebesar -0,013204 dan $t_{\text {statistic }}$ sebesar -2,018906 dengan nilai probability sebesar 0,0454 sama besar dari 0,05 atau $(0,0454<0,05)$. Sehingga perencanaan pajak mampu memoderasi pengaruh kepemilikan institusi terhadap nilai perusahaan. Maka dapat disimpulkan bahwa variabel kepemilikan institusi (KI) secara parsial berpengaruh positif dan signifikan terhadap nilai perusahaan (PBV) dengan perencanaan pajak sebagai variabel moderasi pada perusahaan manufaktur yang dibatasi dengan sektor barang dan konsumsi yang terdaftar di Bursa Efek Indonesia tahun 2014-2018. Sehingga Ho ditolak dan Ha diterima.

\subsection{Pembahasan Hasil Penelitian}

1. Pengaruh Corporate Social Responsibility terhadap Nilai Perusahaan

Berdasarkan hasil yang diperoleh dari pengujian terhadap regresi, didapatkan nilai koefisien regresi sebesar 0,083479 dan $t_{\text {statistic }}$ sebesar 4,733305 dengan nilai probability sebesar 0,0000 lebih keci dari 0,05 atau $(0,0000<0,05)$. Maka dapat disimpulkan bahwa variabel corporate social resposibility secara parsial berpengaruh positif dan signifikan terhadap nilai perusahaan pada perusahaan manufaktur yang dibatasi dengan sektor barang dan konsumsi yang terdaftar di Bursa Efek Indonesia tahun 2014-2018. Penelitian ini sejalan dengan penelitian yang dilakukan (Putri et al., 2016) dan (Marius \& Masri, 2017) yang menunjukkan bahwa corporate social responsibility berpengaruh positif terhadap nilai perusahaan.

\section{Pengaruh Dewan Komisaris Independen terhadap Nilai Perusahaan}

Berdasarkan hasil yang diperoleh dari pengujian terhadap regresi,didapatkan nilai koefisien regresi sebesar 0,13706 dan $t_{\text {statistic }}$ sebesar 1,619671 dengan nilai probability sebesar 0,1075 lebih besar dari 0,05 atau $(0,1075>0,05)$. Maka dapat disimpulkan bahwa variabel corporate social resposibility secara parsial berpengaruh positif dan tidak signifikan terhadap nilai perusahaan pada perusahaan manufaktur yang dibatasi dengan sektor barang dan konsumsi yang terdaftar di Bursa Efek Indonesia tahun 2014-2018. Penelitian ini sejalan dengan penelitian yang.dilakukan (Widyaningsih, 2018) yang menunjukkan bahwa komisaris independen berpengaruh positif tetapi tidak signifikan terhadap nilai perusahaan.

3. Pengaruh Kepemilikan Institusional terhadap Nilai Perusahaan

Berdasarkan hasil yang diperoleh dari pengujian terhadap regresi,didapatkan nilai koefisien regresi sebesar 0,001929 dan $t_{\text {statistic }}$ sebesar 0,360733 dengan nilai probability sebesar 0,7188 lebih besar dari 0,05 atau $(0,7188>0,05)$. Maka dapat disimpulkan bahwa variabel kepemilikan institusional secara parsial berpengaruh positif dan tidak signifikan terhadap nilai perusahaan pada perusahaan manufaktur yang dibatasi dengan sektor barang dan konsumsi yang terdaftar di Bursa Efek Indonesia tahun 2014-2018. Penelitian ini sejalan dengan penelitian yang dilakukan (Widyaningsih, 2018) dan (Pratiwi et al., 2016) yang menunjukkan bahwa kepemilikan institusional berpengaruh positif tetapi tidak signifikan terhadap nilai perusahaan.

4. Pengaruh Corporate Social Responsibility terhadap Nilai Perusahaan dengan Perencanaan Pajak sebagai Variabel Moderasi

Berdasarkan hasil yang diperoleh dari pengujian terhadap regresi, didapatkan nilai koefisien regresi sebesar sebesar -0,006536 dan $t_{\text {statistic }}$ sebesar -0,216823 dengan nilai probability sebesar 0,8287 lebih besar dari 0,05 atau $(0,8287>0,05)$. Sehingga perencanaan pajak dapat memperlemah pengaruh corporate social responsibility terhadap nilai perusahaan. Maka dapat disimpulkan bahwa variabel corporate social responsibility secara parsial berpengaruh positif dan tidak signifikan terhadap nilai perusahaan dengan perencanaan pajak variabel moderating pada perusahaan manufaktur yang dibatasi dengan sektor barang dan konsumsi yang terdaftar di Bursa Efek Indonesia 
tahun 2014-2018. Penelitian ini tidak sejalan dengan penelitian yang dilakukan (Iqbal \& Putra, 2018) yang menunjukkan bahwa perencanaan pajak memperkuat pengaruh hubungan corporate social responsibility terhadap nilai.

5. Pengaruh Dewan Komisaris Independen terhadap Nilai Perusahaan dengan Perencanaan Pajak sebagai Variabel Moderasi

Berdasarkan hasil yang diperoleh dari pengujian terhadap regresi, didapatkan nilai koefisien regresi sebesar sebesar 0,012963 dan $t_{\text {statistic }}$ sebesar 1,060446 dengan nilai probability sebesar 0,2908 lebih besar dari 0,05 atau $(0,2908>0,05)$. Sehingga perencanaan pajak dapat memperlemeh pengaruh dewan komisaris independen terhadap nilai perusahaan. Maka dapat disimpulkan bahwa variabel dewan komisaris independen secara parsial berpengaruh positif dan tidak signifikan terhadap nilai perusahaan dengan perencanaan pajak variabel moderating pada perusahaan manufaktur yang dibatasi dengan sektor barang dan kosumsi yang terdaftar di Bursa Efek Indonesia tahun 20142018. Penelitian ini tidak sejalan dengan penelitian yang dilakukan (Iqbal \& Putra, 2018) yang menunjukkan bahwa perencanaan pajak memperkuat pengaruh hubungan dewan komisaris independen terhadap nilai.

6. Pengaruh Kepemilikan Institusional terhadap Nilai Perusahaan dengan Perencanaan Pajak sebagai Variabel Moderasi

Berdasarkan hasil yang diperoleh dari pengujian terhadap regresi, didapatkan nilai koefisien regresi sebesar sebesar $-0,013204$ dan $t_{\text {statistic }}$ sebesar -2,018906 dengan nilai probability sebesar 0,0454 sama besar dari 0,05 atau $(0,0454<0,05)$. Sehingga perencanaan pajak dapat memperkuat hubungan kepemilikan institusional terhadap nilai perusahaan. Maka dapat disimpulkan bahwa variabel kepemilikan institusional secara parsial berpengaruh positif dan signifikan terhadap nilai perusahaan denganp perencanaan pajak variabel moderating pada perusahaan manufaktur yang dibatasi dengan sektor barang dan kosumsi yang terdaftar di Bursa Efek Indonesia tahun 20142018. Penelitian ini sejalan dengan penelitian yang dilakukan (Iqbal \& Putra, 2018) yang menunjukkan bahwa perencanaan pajak memperkuat pengaruh hubungan kepemilikan institusional terhadap nilai perusahaan.

\section{Kesimpulan}

Berdasarkan kepada analisis dengan pembahasan hasil pengujian hipotesis maka dapat diajukan beberapa kesimpulan penting yang merupakan inti dari masalah yang dibahas dalam penelitian ini, yaitu :

1. Corporate Social Responsibility berpengaruh positif dan signifikan terhadap Nilai Perusahaan pada perusahaan manufaktur yang dibatasi dengan sektor barang dan konsumsi yang terdaftar di Bursa Efek Indonesia pada tahun 2014-2018.

2. Dewan Komisaris Independenberpengaruh negatif dan tidak signifikan terhadap Nilai pada perusahaan manufaktur yang dibatasi dengan sektor barang dan konsumsi yang terdaftar di Bursa Efek Indonesia pada tahun 2014-2018.

3. Kepemilikan Institusionalberpengaruh positif dan tidak signifikan terhadap Nilai Perusahaan pada perusahaan manufaktur yang dibatasi dengan sektor barang dan konsumsi yang terdaftar di Bursa Efek Indonesia pada tahun 2014-2018.

4. Perencanaan Pajak dapat memperlemah pengaruh hubungan Corporate Social Responsibilityterhadap Nilai Perusahaan pada perusahaan manufaktur yang dibatasi dengan sektor barang dan konsumsi yang terdaftar di Bursa Efek Indonesia pada tahun 2014-2018.

5. Perencanaan Pajak dapat memperlemah pengaruh hubungan Dewan Komisaris Independen terhadap Nilai Perusahaan pada perusahaan manufaktur yang dibatasi dengan sektor barang dan konsumsi yang terdaftar di Bursa Efek Indonesia pada tahun 2014-2018.

6. Perencanaan Pajak dapat memperkuat pengaruh hubungan Kepemilikan Institusional terhadap Nilai Perusahaan pada perusahaan manufaktur yang dibatasi dengan sektor barang dan konsumsi yang terdaftar di Bursa Efek Indonesia pada tahun 2014-2018. 


\section{Daftar Pustaka}

[1] Anggraini, F. R. R. (2016). Pengungkapan Informasi Sosial dan Faktor-faktor yang Mempengaruhi Pengungkapan Informasi Sosial dalam Laporan Keuangan Tahunan. Simposium Nasional Akuntansi IX, 23-26.

[2] Ardiyanto, T., \& Haryanto. (2017). Pengaruh Pengungkapan Corporate Social Responsibility Terhadap Nilai Perusahaan Dengan Kinerja Keuangan Sebagai Variabel Intervening. Jurnal of Accounting, 6(4).

[3] Endraswati, H. (2017). Struktur Islamic Corporate Governance dan Kualitas Pengungkapan Laporan Keuangan pada Bank Syariah di Indonesia. Salatiga: LP2MPress.

[4] Haruman, T. (2018). Struktur Kepemilikan, Keputusan Keuangan Dan Nilai Perusahaan. Jurnal Keuangan \& Perbankan Perbanas.

[5] Herry. (2015). Controllership Knowledge and Management Approach. Jakarta: PT. Gramedia.

[6] Hery. (2017). Kajian Riset Akuntansi. Jakarta: PT Grasindo.

[7] Iqbal, M., \& Putra, R. J. (2018). Pengaruh Corporate Social Responsibility Dan Good Corporate Governance Terhadap Nilai Perusahaan Dengan Perencanaan Pajak Sebagai Variabel Moderating. Media Studi Ekonomi, 21(1).

[8] Jensen, M., \& Meckling, W. (1976). Theory Of The Firm: Managerial Behavior, Agency Costs And Ownership Structure. Journal of Financial Economics, 3(4), 305360.

[9] Khotimah, H. (2014). Pengaruh Perencanaan Pajak Terhadap Manajemen Laba. Jurnal Bisnis Dan Manajemen, 4(2), 170-177.

[10] Marius, M. E., \& Masri, I. (2017). Pengaruh Good Corporate Governance Dan Corporate Social Responsibility Terhadap Nilai Perusahaan. Konferensi iImiah Akuntansi IV, 118-119.

[11] Pohan, C. A. (2016). Manajemen perpajakan strategi perencanaan pajak dan bisnis (revisi). jakarta: PT Gramedia Pustaka Utama.

[12] Pradnyana, I. B. G. P., \& Noviari, N. (2017). Pengaruh Perencanaan Pajak Terhadap Nilai Perusahaan dengan Transparansi Perusahaan sebagai Variabel Moderasi. E-Jurnal Akuntansi Universitas Udayana, 18(2), 1398-1425.

[13] Prantama, A. N., Suhadak, \& Topowijono. (2015). Pengaruh Penerapan Good Corporate Governance Terhadap Kinerja Keuangan. Jurnal Administrasi Bisnis Volume, 1(2), 1-6.

[14] Pratiwi, M. I., Kristanti, F. T., \& Mahardika, D. P. K. (2016). Pengaruh Kepemilikan Manajerial, Kepemilikan Institusional, Dan Leverage Terhadap Nilai Perusahaan. EProceeding of Management, 3(3), 3191-3197.

[15] Putri, A. K., Sudarma, M., \& Purnomosidhi, B. (2016). Pengaruh Corporate Social Responsibility terhadap Nilai Perusahaan dengan Ukuran Perusahaan dan Jumlah Dewan Komisaris sebagai Variabel Pemoderasi ( Studi pada Perusahaan Manufaktur yang terdaftar Bursa Efek Indonesia ). Jurnal Aplikasi Manajemen, 344.

[16] Rimardhani, H., Hidayat, R. R., \& Dwiatmanto. (2016). Pengaruh Mekanisme Good Corporate Governance Terhadap Profitabilitas Perusahaan. Jurnal Administrasi Bisnis, $31(1)$.

[17] Ross, Stephen, A., \& Westerfield, R. W. (2015). Pengantar Keuangan Perusahaan. Jakarta: Salemba Empat.

[18] Samsul, M. (2006). Pasar Modal dan Manajemen Portfolio. Surabaya: PT. Gelora Aksara Pratama.

[19] Sugiyono. (2017). Metode Penelitian Kuantitatif, Kualitatif, dan R\&B. Bandung: 
Alfabeth.

[20] Sujoko, \& Subiantoro. (2017). Pengaruh Struktur Kepemilikan Saham, Leverage, Faktor Intern dan Faktor Ekstern Terhadap Nilai Perusahaan: Studi Empirik pada Perusahaan Manufaktur dan Non Manufaktur di Bursa Efek Jakarta. Jurnal Manajemen Dan Kewirausahaan, 9, 41-48.

[21] Sulistyowati, \& Ulfah, L. A. (2015). Pengaruh Pengungkapan Corporate Social Responsibility, Profitabilitas, Dan Leverage Terhadap Agresivitas Pajak Pada Perusahaan Manufaktur Yang Terdaftar Di Bursa Efek Indonesia Tahun 2013--2015. Jurnal Balance, 15(2), 237-253.

[22] Widyaningsih, D. (2018). Kepemilikan Manajerial, Kepemilikan Institusional, Komisaris Independen, Serta Komite Audit Terhadap Nilai Perusahaan Dengan Pengungkapan Csr Sebagai Variable Moderating Dan Firm Size Sebagai Variabel Kontrol. Jurnal Akuntansi Dan Pajak, 19(1).

[23] Yuono, C. A. S., \& Widaywati, D. (2016). Pengaruh Perencanaan Pajak Dan Good Corporate Governance Terhadap Nilai Perusahaan. Sekolah Tinggi Ilmu Ekonomi Indonesia (STIESIA). Surabaya. 